\title{
KUALITAS FISIK BISKUIT KONSENTRAT MENGANDUNG INDIGOFERA DENGAN JENIS DAN KONSENTRASI BAHAN PEREKAT BERBEDA
}

\author{
Wati N. ${ }^{1}$, R. A. Muthalib ${ }^{2}$, dan R. Dianita ${ }^{2 *}$ \\ ${ }^{1}$ Mahasiswa Srata Satu, Prodi Peternakan, Fakultas Peternakan Universitas Jambi \\ ${ }^{2}$ Fakultas Peternakan, Universitas Jambi \\ *) coresponding author: rahmi_dianita@yahoo.com
}

\begin{abstract}
ABSTRAK
Kualitas fisik biskuit konsentrat pakan sebagai pakan awetan di antaranya dipengaruhi oleh jenis dan konsentrasi perekat yang digunakan untuk menyatukan bahan-bahan penyusun pakan agar lebih padat. Perekatan bahan-bahan penyusun konsentrat atau pakan komplit akan sangat bergantung pada konsentrasi bahan perekat yang digunakan. Penelitian ini bertujuan untuk mengetahui pengaruh penggunaan berbagai jenis dan konsentrasi bahan perekat terhadap kualitas biskuit pakan konsentrat mengandung Indigofera zollingeriana sebagai pakan ternak kambing. Penelitian ini disusun dengan menggunakan rancangan acak lengkap dengan pola faktorial. Faktor pertama adalah jenis bahan perekat yang terdiri atas molasses, tepung ubi kayu dan tapioka. Faktor kedua adalah konsentrasi bahan perekat yang digunakan yaitu: 3, 5, dan $7 \%$ dari total bahan yang digunakan. Peubah yang diamati dalam penelitian ini adalah kualitas fisik biskuit pakan meliputi uji organoleptik (warna, aroma, dan tekstur), kadar air, berat jenis, aktivitas air, kerapatan bahan, dan ketahanan benturan biskuit yang dihasilkan. Hasil penelitian menunjukkan bahwa jenis bahan perekat berpengaruh nyata $(\mathrm{P}<0,05)$ terhadap hampir di semua peubah yang diamati, Sementara itu untuk konsentrasi bahan perekat berpengaruh nyata $(\mathrm{P}<0,05)$ terhadap kadar air, aktivitas air, kerapatan bahan, dan ketahanan benturan. Interaksi hanya ditemukan pada peubah kadar air dan ketahanan benturan. Dari hasil penelitian dapat disimpulkan bahwa jenis bahan perekat yang terbaik adalah tepung ubi kayu dan konsentrai $5 \%$ merupakan konsentrasi yang terbaik untuk seluruh bahan perekat. Jenis bahan perekat tepung ubikayu pada konsentrasi $5 \%$ adalah yang terbaik.
\end{abstract}

Kata kunci: jenis bahan perekat, konsentrasi, kualitas fisik, biskuit konsentrat pakan

\section{PHYSICAL QUALITY OF BISCUIT CONCENTRATE CONTAINED INDIGOFERA AND SENGON WITH DIFFERENT TYPE AND CONCENTRATION OF ADHESIVE MATERIAL}

\begin{abstract}
Physical quality of biscuit concentrate as preservative feed for livestock is affected by among are the type and concentration of adhesive material which used for binding the ingredient of feedstuff in order to be compact. Adhesive power of the concentrate feed or complete feed ingredients depends on the amount of concentration of binder. This experiments was aimed to reveal the effect of type and concentration of adhesive material on physical quality of biscuit concentrate feed contained Indigofera zollingeriana. The experiment arranged in factorial completely randomized design with two factors. The first was the type of adhesive material consisted of molasses, cassava powder and tapioca flour. The second factor was concentration of adhesive consisted of three level i.e. 3, 5, and $7 \%$ from total ingredients used. Physical quality of biscuit concentrate feed comprised organoleptic test (colour, flavor, texture, and compaction), water content, spesific gravity, material density, impact resistance of biscuit concentrate feed was measured. The result showed that type of adhesive material significantly $(\mathrm{P}<0,05)$ affected of all variables observed, meanwhile the concentration of adhesive material used significantly $(\mathrm{P}<0.05)$ affected only on water content, water activity, material density, and impact resistance of biscuit concentrate feed. The interaction was found only in water content and impact resistance variables. In conclusion that the best type of adhesive material was cassava powder and level of $5 \%$ was the best concentration for binding the biscuit concentrat feed. The biscuit with cassava powder at levels of $5 \%$ was physically best quality.
\end{abstract}

Keywords: type of adhesive material, concentration, physical quality, biscuit concentrate 


\section{PENDAHULUAN}

Biskuit pakan merupakan suatu teknik pengolahan pakan dengan menggunakan pemanasan dan tekanan untuk memperkecil partikel, sehingga memiliki bentuk fisik yang padat agar lebih mudah dalam proses penyimpanan, penanganan serta memiliki daya simpan yang lebih lama (Retnani et al., 2011). Biskuit pakan ternak dapat dibuat baik sebagai biskuit pakan komplit dan atau biskuit pakan konsentrat. Bahan-bahan penyusun biskuit disesuaikan dengan ketersediaan bahan pakan dan kebutuhan ternak. Pakan konsentrat dapat dijadikan dalam bentuk biskuit untuk lebih memudahkan dalam penanganannya, apalagi jika hijauan digunakan sebagai bahan penyusunnya. Secara nutrisi hijauan merupakan sumber serat, namun hijauan yang berasal dari legum dapat menjadi sumber mineral dan protein (Whitehead, 2000), yang juga dapat dijadikan bahan pakan sumber konsentrat hijau bagi ternak ruminansia.

Konsentrat dapat diberikan untuk memperbaiki kualitas pakan rumput alam yang diberikan ke ternak. Indigofera merupakan salah satu legum pakan yang mengandung protein kasar (PK) yang tinggi, yaitu 27,89\%, lemak kasar atau ekstrak eter (EE) sebesar 3,70\%, dan serat kasar (SK) sebesar 14,96\% (Akbarillah et al., 2008) dengan kecernaan bahan kering berkisar $76 \%$ dan kecernaan proteinnya berkisar 83\% (Abdullah, 2010). Hal ini menjadikan Indigofera berpotensi sebagai sumber konsentrat hijau dalam pakan ternak ruminansia sebagai pengganti atau pendamping dalam mengurangi penggunaan konsentrat konvensional, seperti jagung, bungkil kedelei, dan bungkil kelapa.

Beberapa penelitian telah dilakukan tentang pemanfaatan Indigofera sebagai pakan ternak sumber konsentrat pada ternak kambing peranakan etawa (PE). Dalam penelitian sebelumnya, telah dilakukan penelitian tentang suplementasi I. zollingeriana sebagai sumber protein by pass dalam pakan berbasis rumput rawa terhadap produktivitas kambing jantan muda peranakan etawa dan dihasilkan bahwa suplementasi pada level 30\% merupakan yang terbaik dalam meningkatkan produktivitas ternak kambing jantan muda PE, yang tercermin dari pertambahan bobot badan harian, persentase karkas, luas urat daging mata rusuk (udamaru), konsumsi ransum dan efisiensi penggunaan ransum (Muthalib et al., 2017). Namun, dilihat dari produksi gas metan pada Indigofera yang tinggi mengindikasikan tannin yang terkandung dalam Indigofera rendah (Afzalani, 2017komunikasi personal). Hal ini menyebabkan besarnya proporsi protein yang terdegradasi di dalam rumen oleh mikroba yang mengakibatkan rendahnya efisiensi penggunaan protein pakan asal Indigofera. Penelitian dilanjutkan dengan penambahan hijauan sumber tanin
(Albizia falcataria) dalam konsentrat mengandung Indigofera. Hasil penelitian menyimpulkan bahwa penambahan sengon mulai level $2 \%$ sampai dari konsentrat Indigofera yag dipakai dalam ransum sudah mampu menekan produksi $\mathrm{NH}_{3}$, meningkatkan produksi VFA parsial propionat dibandingkan dengan butirat dalam rumen (Muthalib et al., 2018). Dari hasil penelitian tersebut sangat memungkinkan untuk dikembangkan biskuit konsentrat mengandung Indigofera dalam menunjang produktivitas ternak, khususnya ternak kambing.

Dalam pembuatan biskuit pakan, perekat merupakan hal yang sangat penting karena perekat berperan dalam menyatukan atau merekatkan bahanbahan penyusun biskuit sehingga mudah dalam pengemasan, pengangkutan dan penyimpanan. Salah syarat perekat biskuit adalah bahan yang mengandung pati yang tinggi, seperti tepung ubi kayu, molases dan tapioka (Ismi et al., 2017; Sari et al., 2016). Syahri et al. (2018) menyatakan bahwa jenis perekat (binder) dapat mempengaruhi kualitas fisik seperti tekstur, kerapatan tumpukan, ketahan benturan, kadar air dan berat jenis. Menurut Rasulu et al. (2012) kandungan pati tepung ubi kayu yang tidak difermentasi sebesar $79,85 \%$ sedangkan tepung ubi kayu yang difermentasi berkisar 58,55 - 59,86\%. Kandungan pati pada bahan perekat mempengaruhi daya rekat bahanbahan yang dicampurkan. Hal ini juga akan terkait dengan konsentrasi bahan perekat. Syamsu (2007) melaporkan bahwa dengan penggunaan berbagai macam bahan perekat dengan konsentrasi $3 \%$ lebih mampu meningkatkan kualitas fisik pellet yang kompak dengan kerapatan tumpukan dan ketahanan benturan yang baik serta menghasilkan aroma yang segar dan tidak tengik.

Oleh karena itu, penelitian pembuatan konsentrat pakan mengandung Indigofera dan sengon dalam bentuk biskuit dilakukan dengan menggunakan berbagai jenis dan konsentrasi perekat untuk melihat sifat fisik biskuit pakan konsentrat sehubungan dengan pemanfaatannya untuk jangka waktu yang panjang.

\section{MATERI DAN METODE}

Penelitian dilaksanakan di Laboratorium Fakultas Peternakan, Universitas Jambi. Bahan yang digunakan dalam penelitian ini adalah tepung daun Indigofera zollingeriana, jagung halus, bungkil kelapa, bungkil kedelei dan tepung daun sengon, serta tepung ubi kayu. Tempat penyimpanan yang akan dipakai adalah plastik sealed. Alat yang digunakan dalam penelitian adalah timbangan elektrik, plastik, nampan alumunium, kayu pengaduk, kompor gas, cetakan biskuit, wajan, alat press manual dan oven otomatis. 
Rancangan percobaan yang digunakan dalam penelitian ini adalah rancangan acak lengkap dengan pola faktorial. Faktor pertama adalah jenis bahan perekat $(\mathrm{J})$ yang terdiri atas molasses, tepung ubi kayu, dan tapioka. Faktor kedua adalah konsentrasi bahan perekat yang digunakan yaitu: 3,5 , dan $7 \%$ dari total bahan yang digunakan. Peubah yang diamati dalam penelitian ini adalah kualitas fisik biskuit pakan meliputi uji organoleptik (warna, aroma, dan tekstur), kadar air, berat jenis, aktivitas air, kerapatan (densitas), dan ketahanan benturan. Setiap perlakuan diulang 5 kali dan setiap unit perlakuan terdapat 3 unit, sehingga keseluruhan unit percobaan terdapat 60 unit.

Biskuit konsentrat pakan merupakan campuran dari daun Indigofera sp., jagung, bungkil kelapa, bungkil kedelai, sengon, dan molasses. Bahan utama penyusun biskuit konsentrat tercantum pada Tabel 1 .

Tabel 1. Komposisi Bahan Penyusun Konsentrat

\begin{tabular}{|c|c|}
\hline Bahan Pakan & $\%$ \\
\hline \multicolumn{2}{|l|}{ Konsentrat } \\
\hline I. zollingeriana & 30 \\
\hline Dedak & 20 \\
\hline Jagung giling & 20 \\
\hline Bungkil kedele & 12 \\
\hline Bungkil kelapa & 10 \\
\hline Mineral mix ${ }^{1}$ & 1 \\
\hline Garam & 1 \\
\hline Sengon & 6 \\
\hline \multirow{2}{*}{\multicolumn{2}{|c|}{$\begin{array}{l}{ }^{1} \text { Mineral mix per contain : Ca } 165.000 \text { mg, Na } 157.000 \text { mg, Fe } 2.500 \text { mg } \\
\text { mg, Mg } 2.000 \text { mg, I } 125 \text { mg, Co } 50 \text { mg, Zn } 5.000 \text { mg, Se } 10 \text { mg. }\end{array}$}} \\
\hline & \\
\hline Zat makanan & Konsentrat (\%) \\
\hline Bahan Kering (\%) & 90,57 \\
\hline Ash (\%) & 7,66 \\
\hline Protein Kasar (\%) & 16,58 \\
\hline Lemak (EE) (\%) & 7,39 \\
\hline Serat Kasar (\%) & 11,55 \\
\hline BETN (\%) & 48,76 \\
\hline TDN (kg) & 60,50 \\
\hline
\end{tabular}

Keterangan : Berdasarkan Perhitungan Winfeed

\section{Prosedur Pembuatan Biskuit Pakan}

Pembuatan pakan biskuit dilakukan menngacu berdasarkan petunjuk Retnani et al. (2009) yang dimodifikasi yaitu seperti yang tertera pada Gambar 1.

Proses pembuatan biskuit konsentrat pakan dalam penelitian ini melalui beberapa tahap.

1) Persiapan bahan baku dan penimbangan bahan

Indigofera zollingeriana dan sengon dipanen dan kemudian dikeringanginkan di bawah sinar matahari selama 1 sampai 3 hari. Setelah kadar air turun, I. zollingeriana dan sengon digiling dengan mesin grinder untuk dijadikan tepung. Bahan- bahan campuran yang lain yaitu bungkil kelapa, bungkil kedelai, jagung halus, ditimbang sesuai dengan komposisi pakan konsentrat. Kemudian bahan-bahan perekat (molasses, tepung ubi kayu dan tapioka) ditimbang sesuai konsentrasi perlakuan dari berat total bahan penyusun biskuit.

2) Pencampuran

Bahan penyusun biskuit dicampur sampai homogen dan kemudian dicampurkan dengan jenis perekat dan konsentrasinya sesuai dengan perlakuan. Alat press yang digunakan adalah alat press manual, sehingga modifikasi perlu dilakukan dalam pencampuran bahan perekatnya. Sebelum dicampurkan dengan bahan lainnya, bahan perekat terlebih dahulu dilarutkan dengan air panas (suhu $80-90^{\circ} \mathrm{C}$ ) dan kemudian dicampurkan dengan bahan-bahan penyusun konsentrat lainnya. Setelah itu pencetakan dilakukan setelah semua bahan tercampur merata dan pemanasan dilakukan segera setelah pencetakan dengan menggunakan oven selama 1 hari dengan suhu $60^{\circ} \mathrm{C}$, dimaksudkan agar perekat yang dipakai dapat merekatkan bahan-bahan campuran dengan baik. Pencampuran bahan dilakukan dengan secara manual.

3) Pengepresan dan pencetakan biskuit

Bahan baku yang sudah dicampur kemudian dimasukkan ke dalam cetakan biskuit, kemudian dipress menggunakan alat press manual.

4) Biskuit yang telah dicetak langsung dimasukkan ke dalam oven $60^{\circ} \mathrm{C}$ selama 24 jam.

5) Pendinginan biskuit dilakukan dengan menempatkannya pada suhu kamar kira-kira $28^{\circ} \mathrm{C}$. Setelah itu dilakukan pengamatan sifat fisik biskuit pakan konsentrat yang dihasilkan sesuai dengan peubah yang diamati.

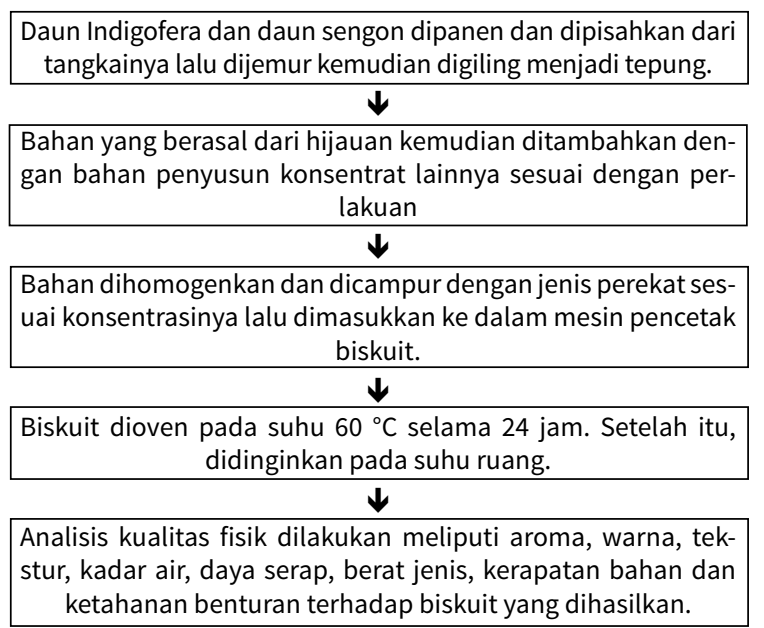

Gambar 1. Proses pembuatan biskuit konsentrat pakan (Retnani et al., 2009) yang dimodifikasi 


\section{Peubah yang Diamati Uji Organoleptik}

Uji organoleptik yang dilakukan meliputi warna dan bau yang dilakukan dengan indra perasa. Dalam uji ini akan terdapat 30 panelis tidak terlatih untuk melakukan penilaian dalam uji ini. Aspek yang diuji akan diberi level berupa angka untuk memudahkan dalam penilaian. Analisis akan dilakukan terhadap angka yang diperoleh dan kemudian akan dikembalikan kepada standarnya.

\section{Kadar Air (\%) dan Aktivitas Air (AW)}

Kadar air diukur dengan metode pemanasan (AOAC, 2005). Sementara itu, untuk mengetahui aktifitas air (Aw) digunakan alat Aw meter yang terlebih dahulu sudah dikalibrasi, nilai aktifitas air (Aw) dihitung dengan membaca skala AW meter.

\section{Berat Jenis (g/ml)}

Berat jenis merupakan perbandingan antara berat bahan dengan volume bahan. Sampel bahan ditimbang sebanyak $20 \mathrm{~g}$. Aquades sebanyak $100 \mathrm{ml}$ dimasukkan ke dalam gelas ukur $250 \mathrm{ml}$ dan kemudian sampel dimasukkan ke dalamnya. Perubahan volume aquades dicatat dan dimasukkan ke dalam perhitungan untuk mencari nilai berat jenis. Rumus untuk menentukan berat jenis adalah (Jaelani, 2007) :

\section{Kerapatan Bahan (Densitas)}

Densitas (kerapatan) diukur dengan cara sampel bahan pakan ditimbang beratnya (g), kemudian diukur jari-jarinya $(\mathrm{cm})$ dan ketebalan biskuitnya $(\mathrm{cm})$.

Nilai kerapatannya dihitung dengan rumus (Trisyulianti et al, 2003):

$$
K=\frac{W}{\left(\pi \cdot r^{2} \cdot T\right)}
$$

Keterangan :

$\mathrm{K}=$ kerapatan $(\mathrm{g} / \mathrm{cm} 3)$

$\mathrm{W}=$ berat uji contoh $(\mathrm{g})$

$\mathrm{r}=$ jari-jari contoh uji $(\mathrm{cm}) \pi=3,14$

$\mathrm{T}=$ tebal contoh uji $(\mathrm{cm})$

\section{Ketahanan Benturan}

Untuk menguji ketahanan biskuit pakan konsentrat terhadap benturan dengan melalukan shatter test yaitu dengan cara menjatuhkan biskuit yang telah diketahui beratnya ke atas sebuah lempeng besi, ketahanan biskuit terhadap benturan dapat dirumuskan sebagai presentase banyaknya bikuit yang utuh setelah dijatuhkan ke atas sebuah lempengan besi terhadap jumlah biskuit semula sebelum dijatuhkan (Balagopalan et al. 1988).

\section{HASIL DAN PEMBAHASAN}

\section{Karakteristik Biskuit Konsentrat}

Uji organoleptik biskuit konsentrat mengandung Indigofera dengan menggunakan berbagai jenis dan konsentrasi bahan perekat tercantum pada Tabel 3 .

Tabel 3. Uji Organoleptik (Warna, Aroma, Tekstur dan Kepadatan) Biskuit Konsentrat Mengandung Indigofera dengan Menggunakan Berbagai Jenis dan Konsentrasi Perekat

\begin{tabular}{|c|c|c|c|c|}
\hline Perlakuan & Warna & Aroma & Tekstur & Kepadatan \\
\hline \multicolumn{5}{|l|}{ Jenis Perekat: } \\
\hline Molases & coklat & Wangi & kasar & kompak \\
\hline Tepung Ubi kayu & $\begin{array}{c}\text { coklat } \\
\text { kehijauan }\end{array}$ & Wangi & kasar & kompak \\
\hline Tapioka & coklat & Asam & kasar & kompak \\
\hline \multicolumn{5}{|l|}{ Konsentrasi Perekat: } \\
\hline Konsentrasi $3 \%$ & $\begin{array}{c}\text { coklat } \\
\text { kehijauan }\end{array}$ & Asam & kasar & remah \\
\hline Konsentrasi 5\% & coklat & Asam & kasar & kompak \\
\hline Konsentrasi $7 \%$ & coklat & Asam & kasar & $\begin{array}{c}\text { sangat } \\
\text { kompak }\end{array}$ \\
\hline
\end{tabular}

Secara umum penggunaan berbagai macam bahan perekat (molases, tepung ubikayu dan tepung tapioka) menghasilkan biskuit konsentrat yang baik; berwarna cokelat, beraroma wangi dengan tekstur yang kasar dan kepadatan yang kompak. Sementara itu, bahan perekat dengan konsentrasi $5 \%$ menghasilkan biskuit yang baik; berwarna cokelat, beraroma asam, kasar dan kompak, dibandingkan dengan biskuit yang dihasilkan pada konsentrasi yang lebih rendah (3\%) lebih remah (mudah hancur), dan konsentrasi yang lebih tinggi (7\%) menghasilkan biskuit yang sangat kompak (keras).

Pengujian secara organoleptik menunjukkan warna biskuit yang dihasilkan berkisar antara hijau sampai cokelat. Biskuit konsentrat mempunyai komposisi 30\% Indigofera dan $6 \%$ sengon serta selebihnya adalah bahan-bahan penyusun konsentrat konvensional lainnya. Warna hijau dimungkinkan karena total hijauan yang digunakan sebanyak 36\% dari total bahan keseluruhan. Komposisi yang cukup banyak dibandingkan bahan-bahan penyusun konsentrat konvensional lainnya. Perubahan warna menjadi coklat kehijauan sampai coklat diduga dengan adanya penambahan bahan perekat dan akibat proses pemanasan biskuit menyebabkan reaksi Mailard terjadi. Selain pemanasan bahan pakan, molases dan tepung ubikayu yang menyumbangkan aroma wangi karena adanya kandungan gula, sehingga aroma yang ditimbulkan umumnya wangi seperti karamel sebagai akibat dari reaksi tersebut. Dari sifat bahannya, perekat molasses dan tapioka mempunyai kadar air dan aktivitas air yang lebih tinggi dibandingkan dengan tepung ubikayu. Hal ini yang diduga menyebabkan 
warna pada biskuit yang menggunakan molasses dan tapioka lebih coklat dibandingkan dengan tepung ubikayu. Reaksi Mailard dipengaruhi oleh temperatur dan waktu dan sangat bergantung pada kondisi saat proses terjadi seperti $\mathrm{pH}$, kandungan air bahan, aktivitas air, komposisi kimia bahan, jenis dan ketersediaan reaktan (Rufia'n-Henares, 2009; Gerrard, 2002). Tingginya kandungan air, temperatur, $\mathrm{pH}$, penurunan gula dan konsentrasi asam amino menyebabkan meningkatnya pembentukan intensitas warna cokelat (Echavarria et al., 2013). Secara umum, pencokelatan yang maksimum terjadi pada bahan dengan aktivitas air antara 0,60 dan 0,85 (Gerrard, 2002). Rata-rata perbedaan warna pada reaksi Mailard dikontrol oleh temperatur dan reaktan. Reaksi Mailard mendorong terjadinya perubahan warna dengan rata-rata perbedaan pengamatan meliputi waktu masing-masing 42, 16, 9, 9, 5, dan 3 jam pada suhu $0,5,10,15,20$, and $25^{\circ} \mathrm{C}$ (Lee et al., 2018).

Tekstur biskuit secara keseluruhan hampir sama yaitu kasar karena menggunakan komposisi bahan yang sama, hanya berbeda konsentrasi penggunaan perekat. Sedangkan bahan perekat yang digunakan berupa cairan dan tepung (sangat halus) dan tidak mempengaruhi tekstur bahan-bahan penyusun konsentrat yang lain.

Kepadatan biskuit secara fisik secara umum dengan menggunakan semua perekat menghasilkan biskuit yang kompak, hanya saja semakin tinggi konsentrasi bahan perekat yang digunakan menjadikan biskuit cenderung sangat kompak/keras. Kondisi pakan yang terlalu kompak/keras dapat mempengaruhi konsumsi ternak terhadap pakan yang diberikan. Saleh (2013) menyatakan bahwa kandungan pati pada bahan perekat juga menyebabkan terjadinya proses gelatinisasi yang mengikat tiap komponen pakan, sehingga pellet menjadi kompak, utuh, dan bobot yang berat.

\section{Kadar Air, dan Ketahanan Benturan Biskuit Konsentrat}

Perlakuan jenis dan konsentrasi bahan perekat serta interaksi keduanya berpengaruhnya nyata $(\mathrm{P}<0,05)$ terhadap kadar air dan ketahanan benturan biskuit konsentrat. Jenis dan konsentrasi bahan perekat terbaik untuk kedua parameter adalah tepung ubikayu dengan konsentrasi $5 \%$.

\section{Kadar Air Biskuit Konsentrat}

Kandungan air (kadar air) dalam suatu bahan pakan atau pakan awetan merupakan hal yang krusial sehubungan dengan tujuan pengawetannya yaitu menyimpan agar dapat digunakan dalam periode waktu yang panjang. Kadar air biskuit
Tabel 4. Kadar Air dan Ketahanan Benturan Biskuit Konsentrat Mengandung Indigofera dengan Menggunakan Berbagai Jenis dan Konsentrasi Perekat

\begin{tabular}{lccc}
\hline \multirow{2}{*}{ Jenis Perekat } & \multicolumn{3}{c}{ Konsentrasi Perekat (\%) } \\
\cline { 2 - 4 } & \multicolumn{3}{c}{ Kadar air (\%) } \\
\hline \multirow{3}{*}{ Molases } & $43,00^{\mathrm{a}} \pm 10,00$ & $29,00^{\mathrm{ab}} \pm 0,50$ & $16,25^{\mathrm{b}} \pm 0,75$ \\
Tepung Ubi kayu & $12,75^{\mathrm{bc}} \pm 0,25$ & $8,50^{\mathrm{c}} \pm 3,89$ & $16,17^{\mathrm{a}} \pm 4,04$ \\
Tapioka & $15,67^{\mathrm{b}} \pm 3,33$ & $17,16^{\mathrm{a}} \pm 3,62$ & $11,50^{\mathrm{bc}} \pm 3,61$ \\
\multicolumn{3}{c}{ Ketahanan benturan } \\
Molases & $22,23^{\mathrm{b}} \pm 1,48$ & $94,20^{\mathrm{ab}} \pm 0,08$ & $99,74^{\mathrm{a}} \pm 0,22$ \\
Tepung Ubi kayu & $86,14^{\mathrm{bc}} \pm 5,15$ & $89,01^{\mathrm{b}} \pm 12,71$ & $99,31^{\mathrm{a}} \pm 0,07$ \\
Tapioka & $92,43^{\mathrm{b}} \pm 1,20$ & $97,00^{\mathrm{a}} \pm 1,08$ & $99,88^{\mathrm{a}} \pm 0,20$ \\
\hline
\end{tabular}

Keterangan: Superskrip yang berbeda pada baris yang sama menunjukkan beda nyata $(\mathrm{P}<0,05)$

konsentrat yang menggunakan molases nyata lebih tinggi dibandingkan dengan kadar air biskuit pakan konsentrat yang menggunakan tepung ubi kayu dan tapioka pada seluruh konsentrasi. Menurut Syarief dan Halid (1993) aktivitas mikroorganisme dan enzim dapat ditekan pada kadar air 12-14\%, sehingga bahan tidak mudah berjamur dan membusuk. Dengan demikian, kadar air biskuit yang menggunakan tepung ubikayu dan tepung tapioka masih dalam kisaran yang baik untuk penyimpanan.

Dalam penelitian ini, metode pencampuran bahan perekat yang dimodifikasi dengan menggunakan air panas $80-90^{\circ} \mathrm{C}$ membuat bahan-bahan penyusun konsentrat saling merekat dengan baik. Ditambah lagi, pemanasan dengan menggunakan oven suhu $60^{\circ} \mathrm{C}$ selama 24 jam membantu pengeringan bahan perekat tepung ubi kayu dan tapioka lebih baik dibandingkan dengan molases. Semakin tinggi konsentrasi bahan perekat membuat proses pengeringan sekaligus perekatan bahan menjadi lebih baik. Hal ini juga yang menyebabkan kadar air biskuit pakan konsentrat dengan menggunakan tepung ubi kayu dan tapioka lebih rendah dengan konsentrasi yang lebih tinggi dibandingkan dengan molases. Susilawati et al. (2012) menyatakan bahwa dalam proses pembuatan pelet terjadi pemanasan, sehingga pati dalam bahan perekat akan meleleh membentuk gelatin yang akan menjadi perekat terhadap pelet hijauan yang dibuat.

\section{Ketahanan Benturan Biskuit Konsentrat}

Nilai ketahanan benturan biskuit pakan sangat berhubungan dengan jenis dan konsentrasi bahan perekat yang digunakan. Untuk interaksi antara jenis dan konsentrasi bahan perekat yang terbaik adalah pada seluruh perekat dengan konsentrasi $5 \%$ dengan nilai ketahanan benturan berkisar 89,01 - 97,00\%. Ismi et al. (2017) melaporkan nilai durabilitas pelet dengan menggunakan berbagai konsentrasi molases menunjukkan hasil yang baik yaitu berkisar antara 97-98\%. Krisnan dan Ginting (2009) menyatakan bahwa faktor yang mempengaruhi nilai ketahanan 
benturan (durabilitas) pellet adalah bahan penyusun pellet serta kandungan perekat alami pada bahan pakan dan tingkat perekat tambahan yang diberikan.

\section{Aktivitas Air, Berat Jenis dan Kerapatan Bahan Biskuit Konsentrat}

Hasil penelitian menunjukkan bahwa jenis dan konsentrasi perekat berpengaruh nyata $(\mathrm{P}<0,05)$ terhadap aktivitas air biskuit pakan konsentrat, namun tidak pada interaksinya $(\mathrm{P}>0,05)$. Perekat tepung ubi kayu mempunyai aktivitas air yang nyata $(\mathrm{P}<0,05)$ lebih rendah dibandingkan dengan perekat molasses dan tapioka. Untuk parameter berat jenis, jenis bahan perekat berpengaruh nyata $(\mathrm{P}<0,05)$ terhadap berat jenis biskuit konsentrat, sementara itu konsentrasi bahan perekat dan interaksi keduanya berpengaruh tidak nyata $(\mathrm{P}>0,05)$. Pengamatan aktivitas air dan berat jenis dari biskuit konsentrat menunjukkan bahwa jenis perekat tepung ubikayu dan konsentrasi 5\% merupakan perlakuan yang terbaik. Sementara itu, hasil penelitian menunjukkan bahwa jenis dan konsentrasi perekat berpengaruh nyata $(\mathrm{P}<0,05)$ terhadap kerapatan bahan biskuit pakan, namun tidak dengan interaksinya. Untuk kerapatan bahan yang terbaik adalah dengan menggunakan tepung tapioka dan konsentrasi $7 \%$.

Tabel 5. Berat Jenis dan Kerapatan Bahan Biskuit Konsentrat Mengandung Indigofera dengan Menggunakan Berbagai Jenis dan Konsentrasi Perekat

\begin{tabular}{lccc}
\hline \multicolumn{1}{c}{ Perlakuan } & Aktivitas Air & $\begin{array}{c}\text { Berat Jenis } \\
\left(\mathrm{g} / \mathrm{cm}^{3}\right)\end{array}$ & $\begin{array}{c}\text { Kerapatan Ba- } \\
\text { han }\left(\mathrm{g} / \mathrm{cm}^{3}\right)\end{array}$ \\
\hline Jenis Perekat: & & & \\
Molases & $0,72^{\mathrm{a}} \pm 0,09$ & $1,25^{\mathrm{a}} \pm 0,00$ & $0,67^{\mathrm{b}}+0,07$ \\
Tepung Ubi kayu & $0,69^{\mathrm{b}} \pm 0,07$ & $1,15^{\mathrm{b}} \pm 0,07$ & $0,69^{\mathrm{b}}+0,03$ \\
Tapioka & $0,70^{\mathrm{b}} \pm 0,02$ & $1,17^{\mathrm{b}} \pm 0,07$ & $0,74^{\mathrm{a}+0,04}$ \\
Konsentrasi Perekat: & & & \\
Konsentrasi 3\% & $0,67^{\mathrm{b}} \pm 0,02$ & $1,20 \pm 0,04$ & $0,67^{\mathrm{b}}+0,01$ \\
Konsentrasi 5\% & $0,71^{\mathrm{a}} \pm 0,01$ & $1,17 \pm 0,02$ & $0,69^{\mathrm{b}}+0,01$ \\
Konsentrasi 7\% & $0,72^{\mathrm{a}} \pm 0,01$ & $1,20 \pm 0,04$ & $1,75^{\mathrm{a}}+0,15$ \\
\hline
\end{tabular}

Keterangan: Superskrip yang berbeda pada kolom yang sama menunjukkan beda nyata $(P<0,05)$

\section{Aktivitas Air Biskuit Konsentrat}

Aktivitas air suatu bahan perlu diukur untuk mengetahui batas minimum dari mikroorganisme yang dapat tumbuh dalam bahan didukung dengan kandungan air. Nilai Aw merupakan jumlah air bebas di dalam bahan pangan yang dapat digunakan untuk pertumbuhan mikroba dan berlangsungnya reaksi kimia dan biokimia (Syarief dan Halid, 1993). Nilai Aw biskuit yang dihasilkan berkisar antara 0,67 0,72. Semakin tinggi konsentrasi bahan perekat yang digunakan meningkatkan nilai aktivitas air pada biskuit konsentrat. Tingginya aktivitas air pada molases dan tapioka diduga proses pemanasan pada saat pembuatan biskuit belum sempurna, sehingga bahan masih lembab ketika dibiarkan pada suhu ruang. Hal ini terlihat dari bagian bawah biskuit yang lembab ketika biskuit dibalikkan. Kondisi ini memungkinkan terjadinya aktivitas mikroorganisme - kapang yang menyebabkan meningkatnya nilai Aw. Menurut Buckle et al. (1987), nilai aktivitas air yang naik disebabkan adanya metabolisme mikroorganisme yang umumnya diikuti pelepasan air, sehingga mengakibatkan naiknya Aw pada bahan pangan. Aktivitas air sangat berpengaruh terhadap pertumbuhan mikroba, persyaratan minimal bagi mikroba dapat hidup untuk bakteri adalah 0,9 , khamir (o,80- 0,90) dan kapang (o,60-0,70) (Winarno 2007).

\section{Berat Jenis Biskuit Konsentrat}

Berat jenis bahan akan menentukan kemampuan bahan untuk bisa bercampur satu dengan lainnya dengan baik. Berat jenis biskuit konsentrat dengan menggunakan molases $\left(1,25 \mathrm{~g} / \mathrm{cm}^{3}\right)$ nyata lebih tinggi dibandingkan dengan tepung ubi kayu $\left(1,15 \mathrm{~g} / \mathrm{cm}^{3}\right)$ dan tapioka $\left(1,17 \mathrm{~g} / \mathrm{cm}^{3}\right)$. Komposisi dan ukuran partikel bahan penyusun biskuit konsentrat semuanya sama, yang menbedakan hanya bahan perekat dan konsentrasinya dalam setiap perlakuan. Jenis bahan perekat dengan konsentrasinya akan mempengaruhi komposisi dari biskuit konsentrat. Suadnyana (1998) menyatakan bahwa berat jenis dipengaruhi oleh komposisi kimia bahan pakan.

\section{Kerapatan Bahan Biskuit Konsentrat}

Prinsip pemadatan biskuit adalah merapatkan partikel bahan-bahan penyusun biskuit agar biskuit pakan yang diperoleh lebih kompak dan padat. Biskuit pakan yang mempunyai kerapatan tinggi akan memberikan penampilan kepadatan yang kompak dan keras. Bahan perekat molases mempunyai nilai kerapatan yang kecil $\left(0,67 \mathrm{~g} / \mathrm{cm}^{3}\right)$ dibandingkan dengan tepung ubi kayu $\left(0,69 \mathrm{~g} / \mathrm{cm}^{3}\right)$ dan tapioka $\left(0,74 \mathrm{~g} / \mathrm{cm}^{3}\right)$. Semakin meningkat konsentrasi bahan perekat yang digunakan, semakin meningkat nilai kerapatan biskuit pakan konsentrat yang dihasilkan (kisaran 0,67-1,75 g/ $\mathrm{cm}^{3}$ ). Selain itu, tingginya kadar air pada biskuit dengan bahan perekat molases juga menjadi penyebab nilai kerapatannya kecil. Menurut Retnani et al. (2009) bahwa semakin meningkatnya kadar air wafer menyebabkan ruangan yang diisi air lebih banyak sehingga kerapatan wafer menurun.

\section{SIMPULAN DAN SARAN}

Kualitas fisik biskuit konsentrat mengandung Indigofera yang terbaik dalam penelitian ini adalah yang menggunakan jenis bahan perekat tepung ubi kayu, dan konsentrasi bahan perekatnya adalah 
5\% yang dilihat dari kualitas fisik biskuit pakan konsentrat secara keseluruhan. Interaksi antara jenis perekat dengan konsentrasi yang digunakan dalam pembuatan biskuit menunjukkan bahwa semua bahan perekat baik digunakan dengan konsentrasi 5\% yang ditunjukkan oleh nilai ketahanan benturan biskuit pakan konsentrat yang berhubungan dengan penerapan ke ternak.

Diperlukan penelitian lebih lanjut yang mengarah pada waktu penyimpanan biskuit agar diketahui daya simpan biskuit untuk jangka panjang.

\section{UCAPAN TERIMA KASIH}

Penelitian ini merupakan bagian dari Penelitian Percepatan Guru Besar Tahun DIPA PNBP LPPM Tahun Anggaran 2019 dengan Surat Perjanjian Kontrak Penelitian Nomor: B/1588/UN.21.18/ PT.01.03/2019 Tanggal 17 Mei 2019.

\section{DAFTAR PUSTAKA}

Abdullah L. 2010. Herbage production and quality of shrub Indigofera treated by different concentration of foliar fertilizer. Met. Pet. 33: 169-175.

Akbarillah T, Kususiyah, D. Kaharuddin dan Hidayat. 2008. Kajian tepung daun Indigofera sebagai suplemen pakan terhadap produksi dan kualitas telur puyuh. Jurnal Peternakan Indonesia. 3: 20-23.

AOAC. 1990. Official Method of Analysis of AOAC. United State of America.

Buckle KA, Edwards RA, Fleet GH, Wooton M. 1987. Ilmu Pangan. Hari Purnomo dan Adino, penerjemah. Jakarta: UI Press. Terjemahan dari : Food Science

Echavarria, A. P., J. Pagan, dan Ibarz. 2013. Antioxidant activity of the melanoidin fractions formed from D-Glucose and D-Fructose with L-Asparagine in the Maillard reaction. Scientia Agropecuaria, 4: 45-54.

Gerrard, J. 2002. New Aspects of an AGEing Chemistry - Recent Developments Concerning the Maillard Reaction. Australian Journal of Chemistry, 55(5): 299-310.

Ismi R. S., R. I. Pujaningsih, dan S. Sumarsih. 2017. Pengaruh penambahan level molases terhadap kualitas fisik dan organoleptik pellet pakan kambing periode penggemukan. Jurnal Ilmiah Peternakan Terpadu Vol. 5(3): 58-63

Krisnan, R. dan S. P. Ginting. 2009. Penggunaan solid ex-decanter sebagai binder pembuatan pakan komplit berbentuk pellet : Evaluasi fisik pakan komplit berbentuk pellet. Seminar Nasional Teknologi Peternakan dan Veteriner. Bogor, 13
- 14 Agustus 2009; $480-486$.

Lee J. H, S. Kawamura and S. Koseki. 2018. Quantitative evaluation of changes in color during Maillard reaction for development of novel timetemperature integrators/indicators. Food Science and Technology Research, 24 (2); 283-287.

Muthalib, R. A., R. Dianita, dan Afzalani. 2017. Suplementasi $I$. zollingeriana sebagai sumber protein by pass dalam pakan berbasis rumput rawa terhadap produktivitas kambing Peranakan Etawa. Seminar Nasional VI HITPI, "Peran Strategis Tumbuhan Pakan dalam Mendukung Upsus Siwab untuk Mewujudkan Ketahanan Pangan” Jambi, 23 - 24 November 2017

Muthalib, R. A., R. Dianita, dan Afzalani.2018. Penambahan Hijauan Sumber Tannin sebagai Protektor dalam Penggunaan Konsentrat Hijau Indigofera terhadap Performa dan Kualitas Karkas Kambing Jantan Muda PE. Laporan Penelitian. Fakultas Peternakan, Universitas Jambi

Rasulu H, S. Sudarminto., Yuwono., J. Kusnadi. 2012. Karakteristik tepung ubi kayu terfermentasi sebagai bahan pembuatan sagukasbi. Jurnal Teknologi Pertanian Vol. 13 No. 1 pp 1-7

Retnani, Y., L. Herawati., W. Wirdiati., dan E. Indahwati. 2009. Uji kualitas sifat fisik dan palatabilitas biskuit limbah tanaman jagung sebagai substitusi sumber serat untuk domba. Bul. Peternak. 33: 162-169.

Retnani, Y., I. Wijayanti. N. R. Kumalasari. 2011. Produksi biskuit limbah tanaman jagung sebagai pakan komersil ternak ruminansia. J. Ilmu Peternak. Indonesia. Vol 16 (1): 59-64.

Rufia'n-Henares, J.A., Delgado-Andrade, C. and Morales, F.J. 2009. Assessing the Maillard reaction development during the toasting process of common flours employed by the cereal products industry. Food Chemistry, 114(1): 93-99.

Saleh, A. 2013. Efisiensi konsentrasi perekat tepung tapioka terhadap nilai kalor pembakaran pada biobriket batang jagung ( Zea mays L .). J. Teknosains 7, 78-89.

Sari, M. 2016. Pemanfaatan limbah jagung untuk pembuatan biskuit pakan hijauan di Kecamatan Lima Kaum Batusangkar. Journal of Sainstek 8(2): 166-172

Suadnyana, I W. 1998. Pengaruh kandungan air dan ukuran partikel terhadap perubahan sifat fisik pakan lokal sumber protein. [Skripsi]. Bogor: Institut Pertanian Bogor.

Susilawati I., Mansyur, dan R. Z. Islami. 2012. Penggunaan berbagai bahan pengikat terhadap kualitas fisik dan kimia pelet hijauan makanan ternak (Effect of binder on physical and chemical 
quality of grass pellet). Jurnal Ilmu Ternak, 12 (1); $47-50$

Syahri, M., Y. Retnani, and L. Khotijah. 2018. Evaluasi penambahan binder berbeda terhadap kualitas fisik mineral wafer. Bul. Makanan Ternak 16, 24-35.

Syamsu, J. A. 2007. Karakteristik fisik pakan itik bentuk pellet yang diberi bahan perekat berbeda dan lama penyimpanan yang berbeda ( Phyical characterisics of duck ration in pellet form that added various different agglutinants and different storage times ). J. Ilmu Ternak 7, 128-134.
Syarief, R dan H. Halid. 1993. Teknologi Penyimpanan Pangan. Penerbit Arcan. Pusat Antar Universitas Pangan dan Gizi, Institut Pertanian Bogor. Bogor. Trisyulianti, E., Suryahadi dan V. N. Rakhma. 2003. Pengaruh penggunaan molases dan tepung gaplek sebagai bahan perekat terhadap sifat fisik wafer ransum komplit. Med. Pet. 26: 35-40.

Whitehead, D. C. 2000. Nutrient Element in Grassland: Soil-Plant-Animal Relationship. CAB International Publishing. Wallingford

Winarno, F. G. 2007. Teknobiologi Pangan. M Brio Press, Bogor. 